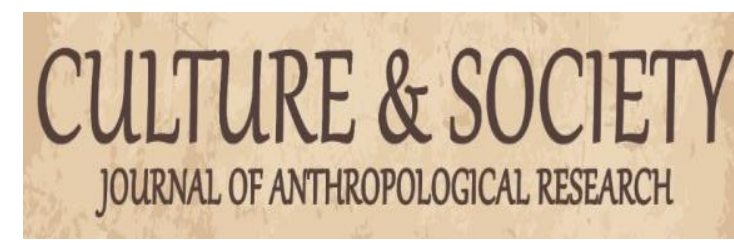

Culture \& Society: Journal of Anthropological Research

VOL. 2 NO. 3 MARET 2021

http://culture.ppj.unp.ac.id

Email: culture@ppj.unp.ac.id

ISSN: 2686-343X (E-ISSN) 2686-3421 (P-ISSN)

DOIः https://doi.org/10.24036/csjar.v2i3.68

\title{
Persepsi Masyarakat Terhadap Perempuan Bercadar Pada Masa Pandemi Covid-19 di Kelurahan Aur Kuning
}

\author{
Yaya Permatasari ${ }^{1}$ Wirdanengsih Wirdanengsih ${ }^{2}$ \\ ${ }^{1,2}$ Universitas Negeri Padang \\ Email: yayapermatasari27@gmail.com
}

\begin{abstract}
Abstrak
Artikel ini bertujuan untuk menjelaskan persepsi masyarakat terhadap perempuan bercadar di Kelurahan Aur Kuning Kota Bukittinggi pada masa pandemi Covid-19. Penelitian ini dilakukan melalui pendekatan kuantitatif dengan metode survey. Pengambilan sampel dilakukan secara random kepada 534 penduduk laki-laki dan perempuan di Kelurahan Aur Kuning dengan batasan usia 25-29 tahun. Pengumpulan data dilakukan dengan penyebaran angket kepada 53 responden dan dianalisa dengan teknik analisis statistik deskriptif, erta dijelaskan dengan teori etnosains yang dikembangkan oleh Goodenough. Goodenough menyatakan bahwa perilaku masyarakat suatu kebudayaan tergantung dengan pengetahuan yang ia miliki. Berdasarkan hasil penelitian diperoleh bahwa persepsi masyarakat Kelurahan Aur Kuning pada umumnya responden laki-laki dan perempuan mengetahui cadar. Sedangkan persepsi masyarakat mengenai perempuan bercadar pada masa pandemi Covid-19, sebagian kecil responden perempuan beranggapan cadar juga termasuk sebagai alat penyaring virus covid-19 sedangkan responden laki-laki beranggapan bahwa cadar bukanlah alat penyaringan virus. Perempuan bercadar di sekitar Kelurahan Aur Kuning merasa nyaman menggunakan cadarnya pada masa pandemi Covid-19 dan tetap diperlakukan sama dengan masyarakat lainnya. Berbeda sebelum masa pandemi perempuan becadar merasa terasingkan dan tidak percaya diri dalam bergaul.
\end{abstract}

Kata Kunci: Covid-19, Perempuan bercadar, Persepsi masyarakat

\section{Abstract}

This article aims to explain people's perceptions of veiled women in Aur Kuning, Bukittinggi City during the Covid-19 pandemic. This research was conducted through a quantitative approach with a survey method. Sampling was carried out randomly to 534 male and female residents in Aur Kuning with an age range of 25-29 years. The data were collected by distributing questionnaires to 53 respondents and analyzed using descriptive statistical analysis techniques and explained by the ethnoscience theory developed by Goodenough. Goodenough stated that the behavior of the people of a culture depends on the knowledge they have. Based on the research results, it was found that the perception of the people of Aur Kuning Village in general, male and female respondents know the veil. While the public's perception of women wearing a veil during the Covid-19 pandemic, a small proportion of female respondents thought that the veil was also a filtering tool for the Covid-19 virus, while male respondents thought that the veil was not a virus filtering tool. Veiled women around Aur Kuning Village felt comfortable wearing the veil during the Covid19 pandemic and were still treated the same as other people. It was different from before the pandemic, that women who were self-conscious felt isolated and did not feel confident in socializing.

Keywords: Covid-19, Veiled women, Public perception.

Received: January 20, $2021 \quad$ Revised: January 28, 2021

Published: January 29, 2021

Culture \& Society: Journal of Anthropological Research Vol. 2, No. 3, Th. 2021 


\section{Pendahuluan}

Indonesia dan dunia sedang diresahkan dengan adanya virus Covid-19. Dimana awal tahun 2020, Umat manusia di seluruh dunia dikejutkan oleh pandemi Virus Corona (Covid-19) yang memunculkan kepanikan serta ribuan lain wafat. Di Indonesia sendiri pemerintah sudah mengimbau masyarakat dalam penanggulangan wabah ini supaya efektif serta efisien.

Ada beberapa protokol kesehatan yang diberikan pemerintah untuk masyarakat Indonesia supaya bebas dari Virus Covid-19, antara lain ialah senantiasa waspada serta tidak panik, jauhi keramaian baik itu tempat tertutup ataupun tempat terbuka, senantiasa melindungi kebersihan tangan dan jauhi menyentuh bagian wajah sebelum mencuci tangan, senantiasa terapkan jaga jarak pada kegiatan sehari-hari, yang utama adalah memakai masker dimana saja serta kapan saja apalagi di dalam ruangan. Menggunakan masker sangatlah dianjurkan karena covid-19 sebab dikira dapat meluas lewat paparan droplet (percikan air liur) dari orang yang terinfeksi Covid-19. Ataupun dapat pula memegang dengan permukaan yang terkontaminasi droplet lalu menyentuh wajah terutama bagian mulut, hidung dan mata.

Berkaitan dengan penggunaan masker, saat sekarang ini tanpa terkecuali masyarakat harus memakai masker di saat ke luar rumah bahkan dalam ruangan, di beberapa daerah juga akan mendenda atau kurungan penjara bagi masyarakat yang tidak memakai masker. Disamping itu ada beberapa masyarakat Indonesia yang mengikuti salah satu sunnah dalam agama Islam yaitu memakai cadar. Peneliti melakukan penelitian terkait cadar dimasa pandemi dikarenakan peneliti melihat adanya persepsi dari masyarakat terhadap perempuan bercadar dimasa pandemi covid-19 ini

Cadar adalah nama yang di peruntukkan bagi pakaian yang berfungsi untuk menutup wajah bagi perempuan dari hidung atau dari bawah lekuk mata kebawah (Sudirman, 2019). Cadar atau niqab juga diartikan sebagai suatu kain penutup wajah, bagi seorang wanita yang menjaga dalam berpakaian istilah acadar sendiri (niqab), adalah syar'I cadar yang digunakan untuk sebagai kain penutup wajah. Niqab dikenakan oleh sebagian kaum perempuan muslim sebagai kesatuan dengan jilbab (hijab). (Ali 2019).

Berbagai berita tentang terorisme yang menyertakan teks atau visual perempuan bercadar membuat perempuan bercadar mendapatkan stigma merujuk pada atribut atau tanda negatif yangg disematkan oleh pihak eksternal pada seseorang sebagai sesuatu yang melekat pada dirinya. Stigma terjadi karena individu memiliki beberapa atribut dan karakter dari identitas sosialnya namun akhirnya terjadi devaluasi pada konteks tertentu. Penangkapan para tersangka tindak terorisme yang terjadi di Indonesia, yang diberitakan secara luas oleh media massa tidak hanya menguak profil seorang teroris, namun juga menampilkan sosok istri-istri pelaku peledakan yang hampir semuanya mengenakan cadar, akhirnya cadar sering dikaitkan dengan haluan pemikiran garis keras yang berpotensi besar dijadikan kelompok yang mendukung aksi terorisme.(Rahman \& Syafiq, 2017).

Mengenai persepsi masyarakat dapat dijelaskan bahwa persepsi sering disebut dengan pandangan, gambaran atau anggapan, dikarenakan persepsi memiliki tanggapan individu mengenai suatu permasalahan. Sedangkan di dalam kamus besar psikologi, persepsi yaitu proses penelitian seseorang terhadap lingkungan dengan menggunakan indra-indra yang dimiliki sehingga menjadi mengerti segala sesuatu yang terdapat di lingkungan individu tersebut. Dimana persepsi memiliki pengertian yang sangat luas, adapun persepsi yang peneliti maksudkan dalam penelitian ini adalah suatu tanggapan atau sudut pandang dari masyarakat terhadap perempuan bercadar (Nursalam \& Syarifuddin, 2017).

Definisi persepsi oleh Kotler (2002) sebagai proses seorang individu dalam memilih, mengorganisasikan dan menafsirkan masukan dan informasi untuk menciptakan sebuah gambar yang bermakna tentang dunia.(Wardhani, Sumarwan, \& Yuliati, 2016) Kata persepsi berasal dari bahasa Inggris "perception" yang artinya penglihatan, tanggapan daya memahami atau menanggapi sesuatu. Sedangkan menurut Kamus Besar Bahasa Indonesia persepsi merupakan

Culture \& Society: Journal of Anthropological Research Vol. 2, No. 3, Th. 2021 
tanggapan (penerimaan) langsung dari sesuatu. Proses seseorang atau individu mengetahui beberapa hal melalui panca inderanya. (Anonym, 2013).

Persepsi menurut Gibson dalam putri menjelaskan bahwa proses kognitif yang digunakan oleh seseorang untuk menafsirkan dan memahami dunia sekitarnya. Setiap orang memiliki berbagai macam isyarat yang mempengaruhi persepsinya terhadap orang, objek, dan tenda. Persepsi mencakup penerimaan stimulus, pengorganisasian stimulus dan penerjemahan atau penafsiran stimulus yang telah diorganisasikan dengan cara yang dapat mempengaruhi perilaku dan pembentukan sikap (Apriliatin, 2010)

Menurut Baron, et. al. (2005) persepsi merupakan proses yang digunakan untuk mencoba mengetahui dan memahami perasaan orang lain. Persepsi inilah yang kemudian akan berlanjut pada realitas yang terjadi secara nyata (Baron, 2004). Menurut Walgito dalam Muhammad Chabib proses terjadinya persepsi dimulai dari adanya objek yang menimbulkan stimulus, dan stimulus mengenai alat indera. Stimulus yang diterima alat indera diteruskan oleh saraf sensoris ke otak. Kemudian terjadilah proses di otak sebagai pusat kesadaran sehingga individu menyadari apa yang dilihat, atau apa yang didengar, atau apa yang dirasa. Tanggapan sebagai akibat dari persepsi dapat diambil oleh individu dalam berbagai macam bentuk. (Chabib 2017)

Covid-19 adalah penyakit yang diakibatkan virus corona jenis baru yang telah muncul tahun 2019 pertama kali di Wuhan, Cina. Cina saat ini menyebabkan pandemi hampir di seluruh penjuru dunia. Gejala utama dari penyakit Covid-19 adalah batuk, demam, dan sesak napas (Kemkes,2020). Infeksi Covid-19 menyebabkan kematian yang cukup tinggi di berbagai belahan negara (Sari et al., 2020).

Sementara itu penularan virus Corona menular lewat lendir (droplet) manusia dengan positif covid-19 dan dapat menular kepada orang yang negatif covid-19. Lendir itu tercipta saat manusia positif covid-19 bersin, batuk, atau berbicara lalu menyebarkan virus ke orang lain(Yunita, 2020). Angka kematian akibat virus Corona di Indonesia tertinggi di Asia setelah Cina, meninggal 181 orang, persentase kematian 9,11\% jumlah kasus virus Corona 1.989 kasus, sembuh 134 orang (Syafrida, 2020).

Terkait perkembangan virus Corona tersebut, akhirnya pemerintah membuat kebijakan sebagai langkah pertama yaitu berupa anjuran social distancing. Pemerintah menganjurkan kepada siapapun yang batuk dan yang menderita penyakit influenza untuk menggunakan masker, tujuannya untuk membatasi percikan droplet (Nurhalimah, 2020).

Peneliti tertarik untuk melakukan penelitian ini dikarenakan terdapat beberapa persepsi masyarakat terhadap perempuan bercadar di Kelurahan Aur Kuning dan saat sekarang ini penggunaan masker dan cadar memiliki kesamaan fungsi dalam pencegahan virus Corona. Dikarenakan hal tersebut, maka peneliti tertarik dengan permasalahan di atas dan melakukan penelitian dengan judul Persepsi Masyarakat terhadap Perempuan Bercadar Pada Masa Pandemi Covid-19 di Kelurahan Aur Kuning Kota Bukittinggi.

\section{Metode Penelitian}

Penelitian ini dilakukan di Kelurahan Aur Kuning Kota Bukittinggi. Alasan pemilihan lokasi penelitian adalah karena peneliti perempuan bercadar dipersepsikan sebelumnya oleh masyarakat sebagai teroris, dan terlihat aneh, selain itu alasan lain karena peneliti melakukan penelitian di masa pandemi Covid-19 dan untuk menghindari penyebaran virus.

Penelitian ini dilakukan dengan pendekatan kuantitatif, penelitian menganalisis serta menjelaskan tentang persepsi masyarakat terhadap perempuan bercadar pada masa pandemi Covid-19. Metode penelitian ini adalah metode survey dengan pendekatan kuantitatif. Metode survey kuantitatif untuk mengumpulkan sejumlah besar variabel mengenai sejumlah besar individu melalui alat pengukur wawancara, kuesioner atau angket. Subjek dalam penelitian ini adalah penduduk laki-lai dan perempuan dan perempuan bercadar di Kelurahan Aur Kuning

Culture \& Society: Journal of Anthropological Research Vol. 2, No. 3, Th. 2021 
yang menjelaskan mengenai pandangan masyarakat terhadap perempuan bercadar di masa pandemi Covid-19.

Teknik pemilihan informan menggunakan teknik random dengan jumlah responden 53 orang perempuan 30 dan laki-laki 23 orang, data dikumpulkan dengan metode penyebaran angket, wawancara, observasi dan dokumentasi. Penelitian ini untuk menjelaskan persepsi masyarakat terhadap perempuan bercadar pada masa pandemi Covid-19 pada masyarakat Kota Bukittinggi.

Alasan peneliti mengambil responden dengan rentang umur 25-29 tahun dikarenakan peneliti mengambil penelitian ini disaat masa pandemi Covid-19 dan banyak dari masyarakat yang tidak mengizinkan untuk menerima tamu, sehingga mempermudah peneliti untuk mempelancar penelitian, dan kenapa peneliti tidak mengambil rentang umur 40-50 dikarenakan pada usia tersebut rentan terkena Covid-19 untuk menjaga kesehatan masyarakat agar terhindar dari virus Corona.

Malhotra dalam Amirullah menyatakan bahwa, populasi merupakan keseluruhan elemen yang memiliki sejumlah karakteristik umum yang terdiri dari bidang-bidang untuk diteliti. Atau populasi adalah keseluruhan kelompok dari orang-orang peristiwa atau barang-barang yang diminati oleh peneliti untuk diteliti (Amirullah, 2015) Jumlah populasi penduduk dari Kelurahan Aur Kuning yaitu:

Tabel 1. Jumlah Populasi Penduduk

\begin{tabular}{cc}
\hline Sampel & Jumlah \\
\hline Usia 25 - 29 tahun (Perempuan) & 300 orang \\
\hline Usia 25-29 tahun ( Laki-laki) & 234 orang \\
\hline Total & 534 Orang \\
\hline
\end{tabular}

Noor menjelaskan Sampel adalah bagian populasi yang diteliti. Penentuan pengambilan sampel yaitu apabila kurang dari 100 lebih baik diambil semua hingga penelitiannya merupakan penelitian populasi (Noor, 2011). Bila jumlah subjeknya besar dapat diambil antara $10-15 \%$ atau 20-55\% atau lebih tergantung sedikit banyaknya dari kemampuan peneliti, dilihat dari waktu, tenaga dan dana, sempit luasnya wilayah pengamatan dari setiap subyek, karena hal ini menyangkut banyak sedikitnya dana, besar kecilnya resiko yang ditanggung oleh peneliti untuk peneliti yang resikonya besar, tentu saja jika sampelnya besar hasilnya akan lebih baik (Arikunto, 2006).

Dalam hal ini peneliti mengambil sebanyak $10 \%$ perempuan yaitu sebanyak 30 orang dan $10 \%$ laki-laki sebanyak 23 orang" untuk lebih jelasnya dapat diterangkan melalui tabel berikut :

Tabel 2. Jumlah Sampel Penduduk

\begin{tabular}{cc}
\hline Sampel & Jumlah \\
\hline Usia 25 - 29 tahun (Perempuan) & 30 orang \\
\hline Usia 25-29 tahun ( Laki-laki) & 23 orang \\
\hline Total & 53 Orang \\
\hline
\end{tabular}

Sumber: Kelurahan Aur Kuning

Dalam penelitian ini digunakan pengelolaan data sebagai berikut:

$$
\mathrm{DP}=\frac{\Sigma \mathrm{y}}{\mathrm{N} \times \Sigma \text { item } \times \text { skala tertinggi }}
$$


keterangan :

$\Sigma y=$ Total skor hasil pengukuran $\mathrm{N} \times \Sigma$ item $\times$ skala tertinggi

$\mathrm{N} \quad=$ Jumlah sampel /responden

$\Sigma$ item $\quad=$ Jumlah butir instrumen

\section{Hasil dan Pembahasan}

\section{Hasil}

\section{Persepsi masyarakat Aur Kuning terhadap perempuan bercadar}

\section{Persepsi Perempuan}

Mengenai persepsi masyarakat Kelurahan Aur Kuning mengenai perempuan bercadar di Kelurahan Aur Kuning. Item 1 berkenaan dengan saya mengetahui apa itu cadar, diperoleh jawaban sebanyak 5 orang $(16,6 \%)$ menjawab sangat setuju 0 orang $(0 \%)$ menjawab kurang setuju, 25 orang $(83,3 \%)$ menjawab setuju, 0 orang $(0 \%)$ menjawab tidak setuju, 0 orang $(0 \%)$ menjawab ragu-ragu. Berdasarkan hal tersebut dapat disimpulkan bahwa pada umumnya masyarakat perempuan mengetahui tentang cadar.

Berkenaan dengan pertanyaan, saya melihat ada beberapa perempuan Aur Kuning menggunakan cadar, diperoleh jawaban sebanyak 2 orang $(6,6 \%)$ menjawab sangat setuju, 8 orang $(26,6 \%)$ menjawab kurang setuju, 15 orang $(50 \%)$ menjawab setuju, 0 orang $(0 \%)$ menjawab tidak setuju, 5 orang $(16,6 \%)$ menjawab ragu-ragu. Berdasarkan hal tersebut dapat disimpulkan bahwa sebagian masyarakat perempuan melihat perempuan bercadar di Kelurahan Aur Kuning.

Berkenaan dengan pertanyaan, saya senang melihat perempuan yang menutup aurat lengkap dengan cadar, diperoleh jawaban sebanyak 9 orang (30\%) menjawab sangat setuju, 15 orang $(50 \%)$ menjawab setuju, 6 orang $(20 \%)$ menjawab ragu-ragu, 0 orang $(0 \%)$ menjawab tidak setuju, 0 orang ( $0 \%$ menjawab kurang setuju. Berdasarkan hal tersebut dapat di simpulkan bahwa sebagian masyarakat senang melihat perempuan menutup aurat menggunakan cadar.

Berkenaan dengan pertanyaan, saya atau saudara perempuan saya berkeinginan menggunakan cadar, diperoleh jawaban sebanyak 4 orang $(13,3 \%)$ menjawab sangat setuju 8 orang (26,6 \%) menjawab kurang setuju, 4 orang (13,3\%) menjawab setuju, 6 orang (20\%) menjawab tidak setuju, 8 orang $(26,6 \%)$ menjawab ragu-ragu. Berdasarkan hal tersebut dapat disimpulkan bahwa sebagian kecil masyarakat belum berkeinginan menggunakan cadar.

Berkenaan dengan pertanyaan, saya merasa perempuan memilih menggunakan cadar itu adalah hal yang baik, diperoleh jawaban sebanyak 13 orang $(43,3 \%)$ menjawab sangat setuju 0 orang $(0 \%)$ menjawab kurang setuju, 17 orang $(56,6 \%)$ menjawab setuju, 0 orang $(0 \%)$ menjawab tidak setuju, 0 orang $(0 \%)$ menjawab ragu-ragu. Berdasarkan hal tersebut dapat disimpulkan bahwa sebagian besar masyarakat merasa menggunakan cadar adalah yang baik.

\section{Persepsi Laki-laki}

Persepsi masyarakat Aur Kuning mengenai perempuan bercadar di Kelurahan Aur Kuning. Item 1 berkenaan dengan saya mengetahui apa itu cadar, diperoleh jawaban sebanyak 9 orang $(39,1 \%)$ menjawab sangat setuju 3 orang $(13,0 \%)$ menjawab kurang setuju, 7 orang $(30,4$ $\%)$ menjawab setuju, 2 orang $(8,6 \%)$ menjawab tidak setuju, 2 orang $(8,6 \%)$ menjawab raguragu. Berdasarkan hal tersebut dapat disimpulkan bahwa sebagian kecil masyarakat mengetahui tentang cadar.

Berkenaan dengan pertanyaan, saya melihat ada beberapa perempuan Aur Kuning menggunakan cadar, di peroleh jawaban sebanyak 5 orang $(21,7 \%)$ menjawab sangat setuju, 3 orang $(13,0 \%)$ menjawab kurang setuju, 9 orang (39,1\%) menjawab setuju, 2 orang $(8,6 \%)$ menjawab tidak setuju, 4 orang (17,3\%) menjawab ragu-ragu. Berdasarkan hal tersebut dapat disimpulkan bahwa sebagian kecil masyarakat perempuan melihat perempuan bercadar di Kelurahan Aur Kuning. berkenaan dengan saya senang melihat perempuan yang menutup aurat 
lengkap dengan cadar diperoleh jawaban sebanyak 2 orang (8,6 \%) menjawab sangat setuju, 14 orang $(60,8 \%)$ menjawab setuju, 7 orang $(30,4 \%)$ menjawab ragu-ragu, 0 orang $(0 \%)$ menjawab tidak setuju, 0 orang $(0 \%)$ menjawab kurang setuju.

Berdasarkan jawaban responden dapat disimpulkan bahwa sebagian besar masyarakat senang melihat perempuan menutup aurat lengkap menggunakan cadar. berkenaan dengan saya atau saudara perempuan saya berkeinginan menggunakan cadar, diperoleh jawaban sebanyak orang $(0 \%)$ menjawab sangat setuju 11 orang $(47,8 \%)$ menjawab kurang setuju, 6 orang $(26,0$ $\%)$ menjawab setuju, 5 orang $(21,7 \%)$ menjawab tidak setuju, 1 orang $(4,3 \%)$ menjawab raguragu. Berdasarkan hal tersebut dapat disimpulkan bahwa sebagian kecil masyarakat belum berkeinginan saudara perempuannya menggunakan cadar.

Berkenaan dengan pertanyaan, saya merasa perempuan memilih menggunakan cadar itu adalah hal yang baik, diperoleh jawaban sebanyak 2 orang $(8,6 \%)$ menjawab sangat setuju 0 orang $(0 \%)$ menjawab kurang setuju, 16 orang $(69,5 \%)$ menjawab setuju, 2 orang $(8,6 \%)$ menjawab tidak setuju, 3 orang (13,0 \%) menjawab ragu-ragu. Berdasarkan hal tersebut dapat disimpulkan bahwa sebagian besar masyarakat merasa perempuan menggunakan cadar adalah yang baik.

\section{Persepsi masyarakat Aur Kuning terhadap perempuan bercadar pada masa pandemi Covid-19}

\section{Persepsi Perempuan}

Persepsi masyarakat Aur Kuning terhadap perempuan bercadar pada masa pandemi Covid-19. Berkenaan dengan pertanyaan, saya lebih setuju kalau perempuan bercadar menggunakan masker dimasa pandemi Covid-19 karena lebih baik dalam penyaringan virus corona, diperoleh jawaban sebanyak 10 orang $(33,3 \%)$ menjawab sangat setuju 5 orang $(16,6 \%)$ menjawab kurang setuju, 13 orang $(43,4 \%)$ menjawab setuju, 0 orang $(0 \%)$ menjawab tidak setuju, 2 orang $(6,6 \%)$ menjawab ragu-ragu. Berdasarkan hal tersebut dapat disimpulkan bahwa sebagian kecil masyarakat setuju jika perempuan bercadar menggunakan masker di masa Covid19. berkenaan dengan Saya merasa cadar bagian dari alat pencegahan penularan virus Covid-19, diperoleh jawaban sebanyak 3 orang (10\%) menjawab sangat setuju 7 orang (23,3\%) menjawab kurang setuju, 17 orang (56,6 \%) menjawab Setuju, 0 orang (0 \%) menjawab tidak setuju, 3 orang (10\%) menjawab ragu-ragu.

Berdasarkan jawaban responden dapat disimpulkan bahwa sebagian besar masyarakat merasa cadar adalah bagian dari termasuk alat pencegahan penularan virus Covid-19. Berkenaan dengan pertanyaan, saya merasa lebih baik perempuan bercadar tetap mengunakan cadarnya di masa pandemi Covid-19, diperoleh jawaban sebanyak 12 orang (40\%) menjawab sangat setuju 2 orang $(6,6 \%)$ menjawab kurang setuju, 13 orang $(43,4 \%)$ menjawab setuju, 0 orang $(0 \%)$ menjawab tidak setuju, 3 orang $(10 \%)$ menjawab ragu-ragu. Berdasarkan hal tersebut dapat disimpulkan bahwa sebagian besar masyarakat berpendapat perempuan bercadar lebih baik tetap menggunakan cadarnya di masa pandemi.

\section{Persepsi Laki-laki}

Persepsi masyarakat Aur Kuning terhadap perempuan bercadar pada masa pandemi Covid-19. Berkenaan dengan pertanyaan, saya lebih setuju kalau perempuan bercadar menggunakan masker dimasa pandemi Covid-19 karena lebih baik dalam penyaringan virus Corona, diperoleh jawaban sebanyak 5 orang $(21,7 \%)$ menjawab sangat setuju 6 orang $(26,0 \%)$ menjawab kurang setuju, 9 orang $(43,4 \%)$ menjawab setuju, 2 orang $(8,6 \%)$ menjawab tidak setuju, 0 orang $(0 \%)$ menjawab ragu-ragu. Berdasarkan jawaban responden dapat disimpulkan bahwa pada umumnya responden perempuan mengetahui tentang cadar. Berkenaan dengan pertanyaan, saya merasa cadar bagian dari alat pencegahan penularan virus Covid-19, diperoleh jawaban sebanyak 1 orang (4,3\%) menjawab sangat setuju 12 orang $(52,1 \%)$ menjawab kurang setuju, 2 orang ( $8,6 \%)$ menjawab Setuju, 0 orang ( 0 \%) menjawab tidak setuju, 8 orang $(34,7 \%)$ menjawab ragu-ragu. 
Berdasarkan jawaban responden dapat disimpulkan bahwa pada umumnya masyarakat perempuan mengetahui tentang cadar. Berkenaan dengan pertanyaan, saya merasa lebih baik perempuan bercadar tetap mengunakan cadarnya di masa pandemi Covid-19, diperoleh jawaban sebanyak 26 orang (8, \%) menjawab sangat setuju 0 orang $(0 \%)$ menjawab kurang setuju, 16 orang $(69,5 \%)$ menjawab setuju, 0 orang $(0 \%)$ menjawab tidak setuju, 5 orang $(21,7 \%)$ menjawab ragu-ragu. Berdasarkan jawaban responden dapat disimpulkan bahwa pada umumnya masyarakat perempuan mengetahui tentang cadar

\section{Persepsi perempuan bercadar Aur Kuning pada masa pandemi Covid-19}

Persepsi perempuan bercadar pada masa pandemi Covid-19. Berkenaan pertanyaan, saya merasa nyaman menggunakan cadar pada masa pandemi covid-19, diperoleh jawaban sebanyak 6 orang $(100 \%)$ menjawab sangat setuju 0 orang $(0 \%)$ menjawab kurang setuju, 0 orang $(0 \%)$ menjawab setuju, 0 orang $(0 \%)$ menjawab tidak setuju, 0 orang $(0 \%)$ menjawab ragu-ragu. Berdasarkan hal tersebut dapat disimpulkan bahwa seluruhnya perempuan bercadar merasa nyaman menggunakan cadar pada masa pandemi Covid-19. Berkenaan dengan pertanyaan, saya tetap diperlakukan sama oleh masyarakat sekitar meskipun menggunakan cadar, diperoleh jawaban sebanyak 4 orang $(66,6 \%)$ menjawab sangat setuju 0 orang $(0 \%)$ menjawab kurang setuju, 2 orang $(33,3 \%)$ menjawab Setuju, 0 orang $(0 \%)$ menjawab tidak setuju, 0 orang $(0 \%)$ menjawab ragu-ragu. Berdasarkan jawaban responden dapat disimpulkan bahwa sebagian besar perempuan bercadar tetap diperlakukan sama oleh masyarakat Kelurahan Aur Kuning. Berkenaan dengan pertanyaan, saya merasa ter asingkan menggunakan cadar sebelum masa pandemi Covid-19, diperoleh jawaban sebanyak 0 orang $(0 \%)$ menjawab sangat setuju 0 orang ( $0 \%)$, menjawab setuju 3 orang (50\%), menjawab Tidak setuju 0 orang $(0 \%)$ dan menjawab ragu-ragu 3 orang $(50 \%)$ berkenaan dengan pertanyaan, saya merasa kurang percaya diri bersosialisasi dengan masyarakat sekitar karena menggunakan cadar sebelum masa pandemi Covid-19, diperoleh jawaban sangat setuju menjawab 0 orang (0\%) kurang setuju menjawab 3 orang $(50 \%)$ setuju menjawab 2 orang $(33,3 \%)$ tidak setuju menjawab 1 orang $(17 \%)$ dan raguragu menjawab 0 orang $(0 \%)$.

\section{Perubahan persepsi masyarakat sebelum dan sesudah masa pandemi Covid-19 terhadap perempuan bercadar}

\section{Persepsi perempuan}

Mengenai perubahan persepsi masyarakat perempuan sebelum dan sesudah masa pandemi Covid-19 terhadap perempuan bercadar. mengenai saya senang melihat perempuan bercadar jauh sebelum masa pandemi Covid-19, diperoleh jawaban Sangat setuju menjawab 0 (0\%) menjawab kurang setuju 9 orang $(30 \%)$ menjawab setuju 4 orang $(13,3 \%)$ menjawab tidak setuju 11 orang $(36,6 \%)$ menjawab ragu-ragu 6 orang $(20 \%)$. Mengenai sebelum masa pandemi saya beranggapan orang bercadar itu aneh, diperoleh jawaban sangat setuju 5 orang $(16,6 \%)$ menjawab kurang setuju 2 orang $(6,66 \%)$ menjawab tidak setuju 4 orang $(13,3)$ menjawab raguragu 4 orang (13,3\%) Mengenai Saya merasa perempuan bercadar itu tidak harus menggunakan cadar dalam kehidupan sehari-hari, diperoleh jawaban sangat setuju 0 orang $(0 \%)$ menjawab kurang setuju 4 orang (13,3\%) menjawab setuju 15 orang (50\%) menjawab tidak setuju 2 orang $(6,66 \%)$ menjawab ragu-ragu 0 orang $(30 \%)$

\section{Persepsi laki-laki}

Perubahan persepsi responden laki-laki sebelum dan sesudah masa pandemi Covid-19 terhadap perempuan bercadar. Mengenai pertanyaan, saya senang melihat perempuan bercadar jauh sebelum masa pandemi Covid-19, diperoleh jawaban Sangat setuju menjawab 0 (0\%) menjawab kurang setuju 15 orang $(65,6 \%)$ menjawab setuju 0 orang $(0 \%)$ menjawab tidak setuju 4 orang $(17,3 \%)$ menjawab ragu-ragu 4 orang $(17,3 \%)$ Mengenai Sebelum masa pandemi saya beranggapan orang bercadar itu aneh, diperoleh jawaban sangat setuju 0 orang $(0 \%)$

Culture \& Society: Journal of Anthropological Research Vol. 2, No. 3, Th. 2021 
menjawab kurang setuju 0 orang ( $0 \%)$ menjawab setuju 20 orang (87\%) menjawab tidak setuju 0 orang $(0 \%)$ menjawab ragu-ragu 3 orang $(13,0 \%)$, Mengenai pertanyaan, saya merasa perempuan bercadar itu tidak harus menggunakan cadar dalam kehidupan sehari-hari diperoleh jawaban sangat setuju 3 orang (13,0 \%) menjawab kurang setuju 0 orang (0\%) menjawab setuju 8 orang $(34,7 \%)$ menjawab tidak setuju 0 orang $(() \%)$ menjawab ragu-ragu 12 orang $(52,1 \%)$.

\section{Pembahasan}

Untuk menjelaskan persepsi masyarakat terhadap perempuan bercadar pada masa Covid19 maka peneliti menganalis dengan menggunakan teori etnosains yang dikembangkan oleh Goodenought atau lebih dikenal dengan istilah Cognitive Antropology yang menekankan bahwa data yang mereka paparkan adalah data kognitif (mental codes). Untuk melihat persepsi masyarakat dipergunakan 10 item indikator persepsi masyarakat. Dimana setiap item indikator akan terlihat jumlah pada frekuensi. Adapun hasil temuan peneliti di lapangan adalah sebagai berikut: dari penyebaran angket, dapat diketahui bahwa dari 30 responden perempuan dan 23 responden laki-laki memberikan jawaban persepsi masyarakat Aur Kuning terhadap perempuan bercadar.

Temuan penelitian menunjukkan bahwa persepsi masyarakat Kelurahan Aur Kuning terhadap perempuan bercadar dapat disimpulkan yaitu 83,3\% responden perempuan dan 39,1\% responden laki-laki mengetahui tentang cadar, $50 \%$ responden perempuan dan 39,1\% responden laki-laki melihat perempuan menggunakan cadar di Kelurahan Aur Kuning, 50 \% responden perempuan dan $60,8 \%$ responden laki-laki senang melihat perempuan menutup aurat lengkap dengan cadar, 26,6 \% responden perempuan dan 47,8 \% responden laki-laki belum berkeinginan jika saudara perempuan mereka untuk menggunakan cadar, 56,6 \% responden perempuan dan $69,5 \%$ responden laki-laki merasa perempuan menggunakan cadar adalah hal yanng baik. Hal ini berarti masyarakat Kelurahan Aur Kuning mengetahui dan mengenal baik tentang perempuan bercadar di Kelurahan Aur Kuning.

Persepsi masyarakat Aur Kuning terhadap perempuan bercadar pada masa pandemi Covid-19, temuan penelitian sebanyak 43,3\% responden perempuan dan 43,4\% responden lakilaki lebih setuju jika perempuan bercadar menggunakan masker dimasa pandemi Covid-19 karena lebih baik dalam penyaringan virus, 56,6 \% responden perempuan merasa cadar termasuk dari alat pencegahan penularan virus Covid-19 sedangkan 52,1\% masyarakat laki-laki merasa cadar bukan termasuk dari alat pencegahan penularan virus Covid-19, 43,3 \% masyarakat perempuan dan 69,5\% responden laki-laki merasa perempuan bercadar lebih baik tetap menggunakan cadarnya dimasa pandemi covid-19. Hal ini berarti bahwasanya cadar dapat digunakan sebagai pengganti masker pada masa pandemi Covid-19, karena cadar juga termasuk sebagai alat penyaringan virus Covid-19.

Persepsi perempuan bercadar pada masa pandemi Covid-19. Temuan penelitian sebanyak $100 \%$ perempuan bercadar merasa nyaman menggunakan cadar pada masa pandemi Covid-19 sedangkan 66,6 \% perempuan bercadar merasa tetap diperlakukan sama oleh masyarakat Kelurahan Aur Kuning meskipun mereka menggunakan cadar dan $50 \%$ perempuan bercadar merasa terasingkan menggunakan cadar sebelum masa pandemi covid-19 dan $50 \%$ perempuan bercadar merasa kurang percaya diri bersosialisasi dengan masyarakat kelurahan Aur Kuning karena menggunakan cadar sebelum masa pandemi Covid-19. Hal ini berarti perempuan bercadar merasa nyaman dan tetap diperlakukan dengan baik oleh masyarakat Kelurahan Aur Kuning selama masa Covid-19 dan perempuan bercadar merasa terasingkan dan tidak percaya diri menggunakan cadar sebelum masa pandemi Covid-19.

Perubahan persepsi masyarakat sebelum dan sesudah masa pandemi Covid-19 terhadap perempuan bercadar. Temuan penelitian sebanyak $36,6 \%$ responden perempuan dan $65,2 \%$ responden laki-laki kurang setuju jika melihat perempuan bercadar sebelum masa pandemi Covid-19 dan $50 \%$ masyarakat perempuan serta $20 \%$ masyarakat laki-laki beranggapan sebelum masa pandemi covid-19 perempuan yang memakai cadar itu aneh dan $50 \%$ responden

Culture \& Society: Journal of Anthropological Research Vol. 2, No. 3, Th. 2021 
perempuan serta52,1 \% responden laki-laki tidak setuju kalau perempuan bercadar menggunakan cadarnya dalam kehidupan sehari-hari Hal ini berarti masyarakat kelurahan Aur Kuning kurang menyukai perempuan memakai cadar sebelum masa pandemi Covid-19.

\section{Kesimpulan}

Berdasarkan penjelasan yang telah penulis paparkan maka dapat ditarik kesimpulan, bahwa persepsi masyarakat Aur Kuning mengenai perempuan bercadar, masyarakat Aur Kuning mengetahui dan mengenal baik tentang perempuan bercadar. Sedangkan persepsi masyarakat Aur Kuning terhadap perempuan bercadar pada masa pandemi Covid-19 mengatakan bahwasanya cadar dapat digunakan sebagai pengganti masker pada masa pandemi covid-19 karena cadar juga termasuk alat penyaringan virus Covid-19. Persepsi perempuan bercadar pada masa pandemi Covid-19 mengatakan bahwa perempuan bercadar merasa nyaman dan tetap diperlakukan dengan baik oleh masyarakat Kelurahan Aur Kuning. Persepsi masyarakat sebelum masa pandemi Covid-19, mereka kurang menyukai perempuan bercadar, dan setelah masa pandemi masyarakat mengenal dengan baik perempuan yang menggunakan cadar dan tidak lagi memiliki stigma negatif terhadap perempuan bercadar.

\section{Daftar Pustaka}

Amirullah, A. (2015). Metode Penelitian Manajemen. Jakarta: Kencana

Anonym. (2013). Pengertian Persepsi. http://eprints.uny.ac.id/9686/3/Bab\%202.Pdf.

Arikunto, S. (2006). Metodologi Penelitian. Yogyakarta: Bina Aksara.

Baron, R. (2004). Psikologi Sosial. Jakarta: Erlangga.

Sudirman, M. (2019). Cadar Bagi Wanita Muslimah (Suatu Kajian Perspektif Sejarah). DIKTUM: Jurnal Syariah dan Hukum. https://doi.org/10.35905/diktum.v17i1.651

Noor, D. J. (2011). Metodologi Penelitian: Skripsi, Tesis, Disertasi, \& Karya Ilmiah. Jakarta: Prenada Media Grup

Nurhalimah, N. (2020). Upaya Bela Negara Melalui Sosial Distancing dan Lockdown Untuk Mengatasi Wabah Covid-19 (Efforts to Defend the Country Through Social Distancing and Lockdown to Overcome the COVID-19 plague). SSRN Electronic Journal. https://doi.org/10.2139/ssrn.3576405

Nursalam, N., \& Syarifuddin, S. (2017). Persepsi Masyarakat Tentang Perempuan Bercadar. Equilibrium: Jurnal Pendidikan, 3(1), 116-125.https://doi.org/10.26618/equilibrium.v3i1.519

Apriliatin, P. (2019). (1912). Hubungan Antara Persepsi Terhadap Kompensasi Dengan Disiplin Kerja Awak Ka Pt. Kereta Api Indonesia (Persero) Daerah Operasi V di Lingkungan Stasiun Besar Purwokerto. Skripsi. Universitas Diponegoro

Rahman, A. F., \& Syafiq, M. (2017). Motivasi, stigma dan coping stigma pada perempuan bercadar. Jurnal Psikologi Teori dan Terapan, 7(2), 103-115.

Sari, M. K. (2020). Sosialisasi Tentang Pencegahan Covid-19 di Kalangan Siswa Sekolah Dasar di SD Minggiran 2 Kecamatan Papar Kabupaten Kediri. Jurnal Karya Abdi Masyarakat, 4(1), 80-83.

Syafrida, S. (2020). Bersama Melawan Virus Covid 19 di Indonesia. SALAM: Jurnal Sosial dan Budaya Syar-i, 7(6), 495-508. https://doi.org/10.15408/sjsbs.v7i6.15325

Wardhani, W., Sumarwan, U., \& Yuliati, L. N. (2016). Pengaruh Persepsi dan Preferensi Konsumen terhadap Keputusan Pembelian Hunian Green Product. Jurnal Manajemen dan Organisasi, 6(1), 45-63. https://doi.org/10.29244/jmo.v6i1.12183

Yunita, N. (2020). Penyebab, Asal Mula, dan Pencegahan Virus Corona di Indonesia. https://news.detik.com/berita/d-4956764/penyebab-asal-mula-dan-pencegahan-virus-corona-diindonesia. 